\title{
Abiotic features of a river from the Upper Tietê River Basin (SP, Brazil) along an environmental gradient
}

\author{
Características abióticas de um rio da Bacia do Alto Tietê (SP, Brasil) ao \\ longo de um gradiente ambiental
}

Katharina Eichbaum Esteves ${ }^{1}$, Ana Valéria Pinto Lôbo ${ }^{2}$ and Alexandre Wagner Silva Hilsdorf ${ }^{3}$

${ }^{1}$ Centro de Pesquisa e Desenvolvimento em Recursos Hídricos, Instituto de Pesca, Secretaria da Agricultura e Abastecimento do Estado de São Paulo, Av. Francisco Matarazzo, 455,

CEP 05001-970, São Paulo, SP, Brazil

e-mail: kesteves@uol.com.br

${ }^{2}$ Programa de Pós-Graduação em Biotecnologia, Universidade de Mogi das Cruzes - UMC, Av. Dr. Cândido Xavier de Almeida Souza, 200, CEP 08780-911, Mogi das Cruzes, SP, Brazil e-mail: anallobo@ig.com.br

${ }^{3}$ Núcleo Integrado de Biotecnologia, Universidade de Mogi das Cruzes - UMC, Av. Dr. Cândido Xavier de Almeida Souza, 200, CEP 08780-911, Mogi das Cruzes, SP, Brazil e-mail:wagner@umc.br

\begin{abstract}
Aim: This study aimed to assess the spatial and seasonal variation of the water quality and physical habitat characteristics along the upper-middle stretch of the Paraitinga River, a tributary of Tietê River, considering the potential influence of different riparian conditions along the stretch studied. Methods: Sixteen sites with different riparian vegetation, including native forest, secondary forest, pasture, and eucalyptus were sampled during the dry and rainy seasons of 2004/2005, before the damming of the Paraitinga Reservoir. Several physicochemical and habitat parameters were determined and data analyzed in relation to spatial distribution and potential influence of riparian conditions. Results: Water quality parameters were in general within the limits established by CONAMA for Class 2 waters, except for turbidity and total phosphorus. There were seasonal and spatial differences in the limnological parameters along the stretch studied and apparently they were related to point specific influences associated with land use and canopy cover. Habitat characteristics were markedly different between the upper and middle river stretches, especially in relation to depth, width, substrate and canopy cover. Conclusions: Although a direct influence on the observed variables could not be attributed solely to the riparian vegetation, vegetation cover seemed to affect particular stream characteristics. Open pasture and eucalyptus sites were subject to point specific effects that caused phosphorus inputs and higher turbidity and temperature, and showed different morphological features, suggesting that land use at the sub-watershed scale was an important factor affecting stream conditions.
\end{abstract}

Keywords: Paraitinga River; riparian vegetation; longitudinal variation; limnology.

Resumo: Objetivo: Este estudo teve como objetivo avaliar a variação espacial e temporal da qualidade da água e as características físicas dos habitats ao longo do trecho médio e alto do Rio Paraitinga, um tributário do Rio Tietê, considerando a possível influência de diferentes condições ripárias ao longo do trecho estudado. Métodos: Foram amostrados dezesseis locais sob diferentes condições ripárias, incluindo floresta nativa, floresta secundária, pasto e eucalipto, durante a estaçáo seca e chuvosa de 2004/2005, previamente ao represamento do reservatório de Paraitinga. Vários parâmetros físicos e químicos da água e do habitat foram registrados e os dados analisados em relação à distribuição espacial e potencial influência das diferentes condiçôes ripárias. Resultados: Os parâmetros de qualidade da água estiveram, em geral, dentro dos limites estabelecidos pelo CONAMA para águas de Classe 2, com exceção de turbidez e fósforo total. Diferenças sazonais e espaciais foram observadas nos parâmetros limnológicos ao longo do trecho estudado, que foram relacionadas à influências pontuais associadas ao uso do solo e à cobertura vegetal. Características do habitat diferiram entre os trechos médio e superior do rio, especialmente em relação à profundidade, largura, substrato e cobertura do dossel. Conclusóes: Apesar de uma influência direta sobre as variáveis analisadas não 
poder ser atribuída exclusivamente à vegetação ripária, diversas características abióticas do rio parecem estar relacionadas à cobertura vegetal. Locais de pasto e eucalipto diferiram quanto às características morfológicas, apresentando também valores mais elevados de fósforo, turbidez e temperatura, o que sugere influências pontuais, indicando que o uso do solo em escala de sub-bacia foi um fator importante que afetou as condiçóes do rio.

Palavras-chave: Rio Paraitinga; vegetação ripária; variação longitudinal; limnologia.

\section{Introduction}

River chemical properties are influenced by many landscape factors that operate on a variety of spatial and temporal scales (Allan, 2004), with geomorphological and hydrological processes acting as the main ecosystem drivers, while chemical and biological factors act as secondary response variables. Thus, hydrogeomorphic variables establish the physical basis under which chemical and biological will operate (Tabacchi et. al., 1998), including catchment soil and geology, chemistry of atmospheric inputs, type and distribution of precipitation, surrounding vegetation, catchment hydrology and land use (Meyer et al., 1988).

Spatial variation in abiotic factors in streams has been attributed to several influences such as the presence of tributaries, longitudinal changes in catchment land use and geology (Meyer et al., 1988). Since the creation of the River Continuum Concept (Vannote et al., 1980) and the Nutrient Spiraling Concept (Newbold et al., 1982), riparian areas have been considered as important compartments of stream ecosystems. Rivers and their riparian areas can be viewed as open ecosystems interconnected longitudinally, laterally and vertically by hydrological and morphological processes that occur within a temporal hierarchy (Ward, 1998). Riparian buffers can reduce the amount of sediment, nutrients, and other contaminants that enter surface waters, and these effects vary from one riparian area to another (Klapproth \& Johnson, 2000).

Nutrients can enter surface waters in subsurface or surface flows in the dissolved form or attached to soil particles (Gilliam et al., 1997). Nitrogen is most commonly transported as dissolved nitrogen through subsurface flows, with peak nitrate levels occurring after crops have been harvested and soil evaporation rates are reduced. In contrast, phosphorus most often enters the stream adsorbed on soil particles and in organic material in surface runoff after storm events (Simóes, 2003). Riparian buffers are effective filters for nutrients, including nitrogen, phosphorus, calcium, potassium, sulfur, and magnesium (Lowrance et al., 1984), but in streams with low nutrient concentrations, a riparian deciduous forest can be a nutrient source for the stream (Mulholland, 1992).

Deforestation with logging operations or agricultural development impacts on Southeast Asian streams has revealed that this activity greatly increases rates of soil erosion and sediment supply to streams (Douglas, 1999). Different forestry practices have also been described as having the potential to degrade water quality and habitat within streams, as found by Maitland et al. (1990) for British rivers. These authors reported that large-scale conifer plantations of upland areas altered the ecology of many rivers, because the high shading prevented the development of herbaceous vegetation, exposing the river banks to erosion and reducing the productivity and biodiversity of the stream. Clear-cutting impacts of Eucalyptus saligna plantations in an experimental catchment in Itatinga (SP) on water quality were observed by Câmara \& Lima (1999), indicating that the most affected water quality parameters were turbidity, color, electrical conductivity and suspended sediments.

The present study focused on the sub-basin of the Paraitinga River, one of the main tributaries on the right bank of the Tietê River, which has been subjected to removal of riparian vegetation in the last decades, showing a mosaic of native forest, secondary forest, pasture and reforestation. This river is located in an area where the cultivation of Eucalyptus is intense, for the purpose of supplying the local paper and cellulose industry. Preserved areas with primary forest or secondary forest represented $35 \%$ of the total area of the Cabeceiras-Tietê catchment in 2001, while reforestation accounted for $13.1 \%$ and pasture $12.9 \%$ of the land use. Between 1988 and 2001, primary forest decreased by $7.7 \%$, while reforestation increased by $27.5 \%$ (Moraes et al., 2005).

Plantations of Eucalyptus outside its natural range has created some concern among limnologists because of its low-quality litter (Bärlocher et al., 1995), as well as because of adverse environmental effects such as soil compaction, soil erosion, nutrient export, pollution and other reported adverse effects (FAO, 1993). Thus, the aim of this study was to 
assess the spatial variation of water quality and of the physical habitat along the Paraitinga River, considering the potential influence of the different riparian conditions along the stretch studied.

\section{Material and Methods}

\subsection{Study area}

The Paraitinga River, located within the Upper Tietê River Basin, is one of the main tributaries of the right bank of the Tietê River, with its headwaters situated at the borders of Paraíba do Sul and Upper Tietê Basins, in the Municipality of Paraibuna (SP). It runs in the east-west direction for approximately $56 \mathrm{~km}$, receiving over its course around 250 small tributaries, and occupies a watershed of $225 \mathrm{~km}^{2}$
(Manna de Deus et al., 2001). After this study, in 2006, the Paraitinga Reservoir was filled in the lower portions of the river, inundating an area of $6.43 \mathrm{~km}^{2}$ to increase water supply for the Metropolitan Region of São Paulo city (Figure 1a).

The climate in the region is within the range of the Cbf (mild summer) and CWb (dry winter) zones, according to the Köppen classification, with total rainfall that varies between 30 and $60 \mathrm{~mm}$ in the driest month (FUSP, 2000). Most of the land in the Paraitinga sub-basin is farmland (29.7\%), followed by secondary forest $(20.8 \%)$, wetlands (20.0\%), urban area (14.0\%), pasture $(12.0 \%)$, reforestation $(3,1 \%)$ and fragments of primary forest $(0.4 \%)$ (IAC, 2006) (Figure 1b).

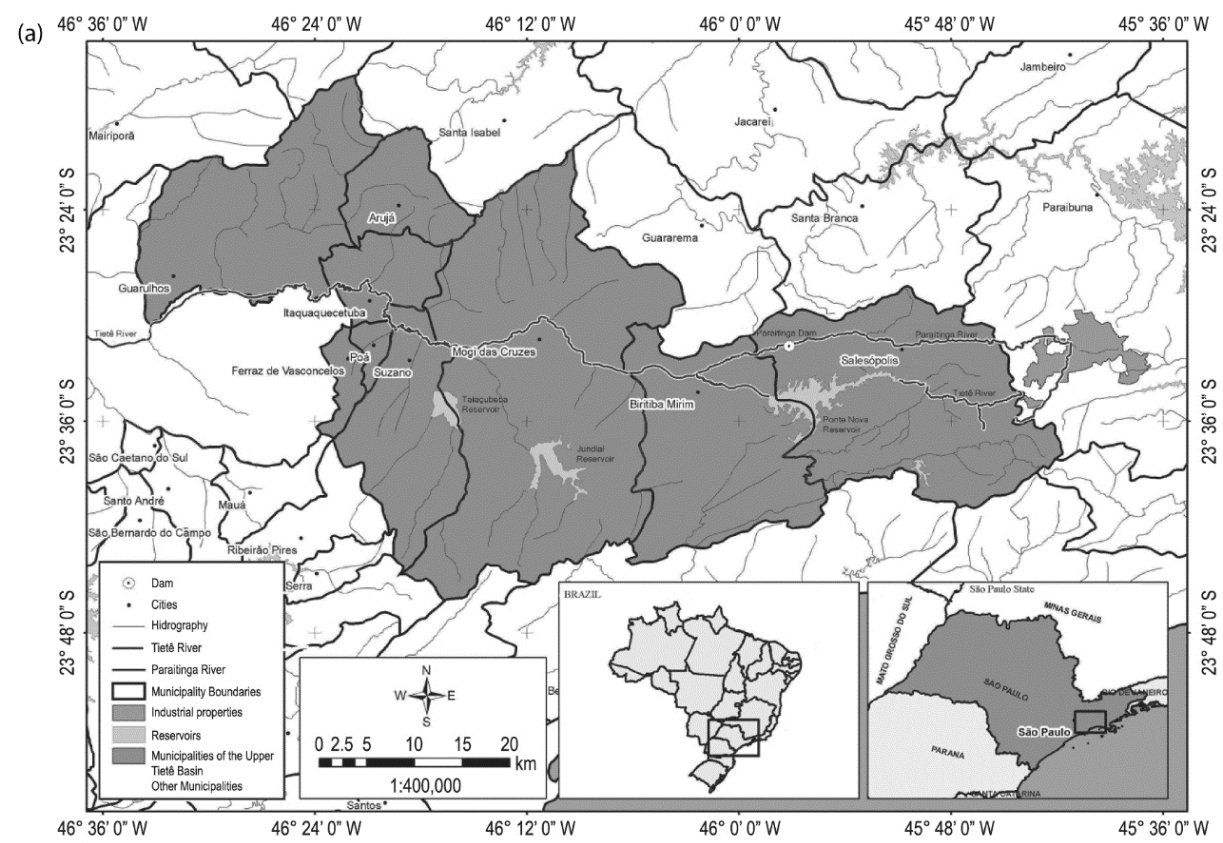

(b)

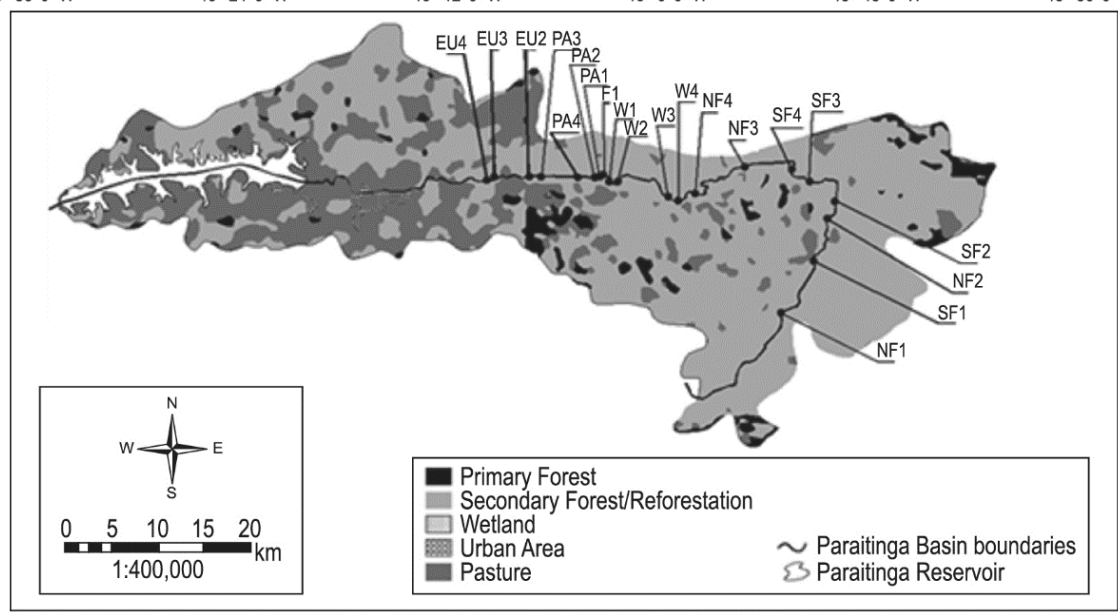

Figure 1. Location of Paraitinga River in Tietê-Cabeceiras sub-basin, Upper Tietê River Basin (a), and major land uses in Paraitinga watershed, indicating the sampling sites from upstream to downstream (b). SF = secondary forest; $\mathrm{NF}$ = native forest; $\mathrm{EU}=$ eucalyptus; $\mathrm{PA}$ = pasture; $\mathrm{W}=$ waterfalls (Esteves et al., 2008). 
Riparian conditions along the Paraitinga River are constituted by a mosaic of pasture, reforestation and secondary and native forests. Its headwaters are surrounded by remains of Atlantic Forest and secondary forest, with the middle course composed of a mosaic of native forest, pasture and Eucalyptus grandis Hill ex Maiden plantations, which extend to the lower portions of the river, where small farms are common. A sequence of runs, riffles and pools is commonly observed within the sample area (Esteves et al., 2008).

The sites studied were located between $S 23^{\circ} 34^{\prime}$ $255^{\prime \prime}, \mathrm{W} 45^{\circ} 42^{\prime} 407^{\prime \prime}$ and S $23^{\circ} 31^{\prime} 519^{\prime \prime}, \mathrm{W} 45^{\circ}$ $48^{\prime} 373^{\prime \prime}$, covering distances that varied from 5.5 to $28 \mathrm{~km}$ from the headwaters. Most sites were of $4^{\text {th }}$ order, with exception of one native forest site (NF1) and one secondary forest site (SF 1) which were of $3^{\text {rd }}$ order. The study sites differed mainly by the degree of anthropogenic alteration of the riparian vegetation and position along the river.

Pasture and eucalyptus sites were located in the middle course, predominantly within private farms where cattle are raised and where eucalyptus plantations are used for charcoal production. Pasture sites differed from other sampling stations by an increase in sinuosity and greater depth, representing an area where an overflow of the river may occasionally occur during the rainy season. Native and secondary forest sites were located in the upper portion of the river, upstream of several waterfalls, in an area which has been mainly used for commercial eucalyptus plantations in the last decades (Esteves et al., 2008).

\subsection{Sampling procedure and data analysis}

Physicochemical water variables and habitat characteristics were obtained at 16 sampling sites along the upper-middle course of the Paraitinga River during the dry (August-September 2004) and rainy season (February-March 2005). Four sites of each of the following riparian conditions were selected: Native Forest (NF), Secondary Forest (SF), Pasture (PA) and Eucalyptus reforestation (EU).

At each sampling site, percent tree canopy shading, depth $(\mathrm{m})$, width $(\mathrm{m})$, water velocity $\left(\mathrm{m} . \mathrm{s}^{-1}\right)$, discharge $\left(\mathrm{m}^{3} \cdot \mathrm{s}^{-1}\right)$, trunk density $(\%)$ and proportion of pools (\%) were recorded. These sites were also characterized in relation to habitat condition using the assessment protocol developed by EPA (Barbour et al., 1999). This method involves 13 parameters related to habitat condition, which are scored on a scale ranging from 0 to 20 points. The individual scores were summed for each station, on a scale that ranged from 0 to 260 points, with the highest values indicating the best conditions; this scale was called the "Habitat quality index."

The following water variables were also measured on the day of sampling: $\mathrm{pH}$, temperature $\left({ }^{\circ} \mathrm{C}\right)$, conductivity $\left(\mu \mathrm{S} . \mathrm{cm}^{-1}\right)$, total dissolved solids (TDS) $\left(\mathrm{mg} . \mathrm{L}^{-1}\right)$, turbidity (NTU) and dissolved oxygen (DO) $\left(\mathrm{mg} . \mathrm{L}^{-1}\right)$, measured with a multi-parameter water quality monitoring system (HORIBA U-22). Nitrate, nitrite, ammonium, dissolved organic phosphorus (DOP) and total phosphorus were determined according to APHA (1998). Sediment samples for analysis of size fractions for each site were taken with an Eckman dredge, and analyzed according to the modified densimeter method (Camargo et al., 2009). Fractions were classified into (in $\mathrm{mm}$ ): very coarse sand, 2 to 0.05 ; silt, $0.05-0.002$; and total clay, $<0.002$.

A multivariate principal components analysis (PCA) was used to ordinate sampling sites and periods in relation to water quality and habitat variables, using PC-ORD 6 software (McCune \& Mefford, 2011). This analysis is considered ideal for reducing a large number of equivalent responses down to a smaller number of summary variables and is effective in identifying patterns that can be modeled linearly (Peck, 2010). Since variables had different units of measurement, the cross-products matrix was based on the correlation, which results in an equal-weighting of all responses (Greig-Smith, 1983). The most important limnological variables selected by the PCA were then analyzed in relation to their spatial distribution along the river.

\section{Results}

The study area has a humid tropical climate. The highest total monthly rainfall was from October 2004 to January 2005 with maximum values of $226 \mathrm{~mm}$, and minimum values were observed in August and September 2004 (dry season). River discharge also varied throughout the year, with values that ranged from 0.5 to $1.6 \mathrm{~m}^{3} \cdot \mathrm{s}^{-1}$ (Figure 2).

Data presented in Table 1 show the mean values of the different physicochemical and habitat variables obtained during the study period, indicating that the waters of the Paraitinga River were slightly acid, with low values of conductivity (maximum of $30 \mu \mathrm{S} . \mathrm{cm}^{-1}$ ) in the rainy season, low concentrations of dissolved oxygen, especially during the dry season ( $\left.4.2 \mathrm{mg} . \mathrm{L}^{-1}\right)$, and higher turbidity at the eucalyptus and pasture sites (up to 150 NTU). Most nutrients, especially the inorganic forms of 
nitrogen (ammonium, nitrate and nitrite), were higher at the pasture and eucalyptus sites, as also observed for total phosphorus, with values as high as $98.1 \mu \mathrm{g} . \mathrm{L}^{-1}$ during the rainy season at the pasture sites. Dissolved Organic Phosphorus (DOP) was similar among different riparian conditions, with the highest value $\left(184.1 \mu \mathrm{g} . \mathrm{L}^{-1}\right)$ measured at eucalyptus sites. At these sites, the habitat index was lowest during the dry season, and at the secondary forest sites during the rainy season, indicating some

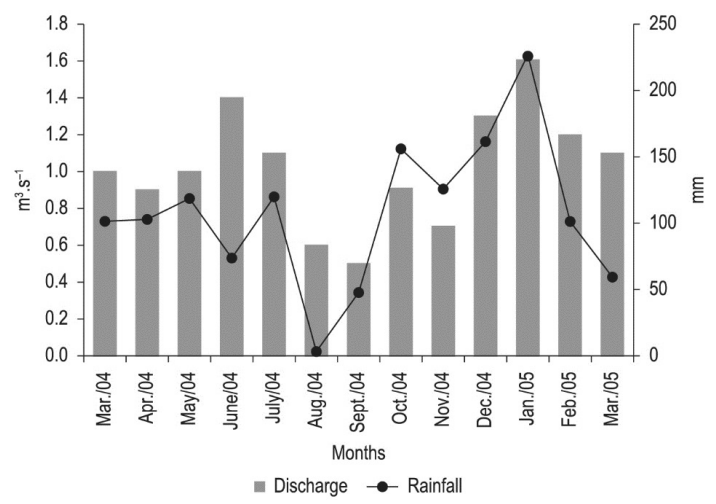

Figure 2. Total monthly rainfall and average monthly discharge of the Paraitinga River for the period of March 2004 to March 2005. Data obtained at DAEE Station no $2 \mathrm{E}-0046$. degree of impairment. The highest values were observed at the secondary forest and pastures sites, during both seasons.

PCA performed with 22 abiotic parameters explained $44.9 \%$ of data variation on the first two axes (Figure 3; Table 2). The scores relative to the seasons were clearly separated by axis 1 , with the dry season samples mostly ordered on the positive side of this axis. The linear (Pearson's $r$ ) relationships between the PCA scores and the individual variables indicated that axis 1 was positively correlated with higher values of $\mathrm{pH}(\mathrm{r}=0.68)$ and trunks $(r=0.66)$, to which NF and SF sites were associated. On the negative side of this axis, pasture and eucalyptus sites were associated with higher values of $\mathrm{NO}_{3}^{-}(\mathrm{r}=-0.87)$, TP $(\mathrm{r}=-0.73)$ and conductivity $(\mathrm{r}=-0.63)$. Component 2 reflected habitat characteristics with canopy cover $(r=0.73)$, silt $(\mathrm{r}=0.70)$ and width $(\mathrm{r}=0.71)$ having a positive relationship with this axis, to which NF and SF sites were associated. On the negative side of this axis, eucalyptus and pasture sites were associated with higher proportion of sand $(\mathrm{r}=-0.64)$, riffles $(\mathrm{r}=-0.50)$ and turbidity $(\mathrm{r}=-0.52)$.

The spatial distribution of the most important physicochemical variables selected by the PCA

Table 1. Water quality and habitat structure (mean and standard deviation, considering the dry and rainy seasons) for the different riparian conditions $(n=8)$ along the Paraitinga River. DOP - dissolved organic phosphorus; HQI - Habitat quality index.

\begin{tabular}{|c|c|c|c|c|c|c|c|c|c|}
\hline & \multicolumn{2}{|c|}{ Native Forest } & \multicolumn{2}{|c|}{$\begin{array}{l}\text { Secondary } \\
\text { Forest }\end{array}$} & \multicolumn{2}{|c|}{ Pasture } & \multicolumn{3}{|c|}{ Eucalyptus } \\
\hline & Mean & SD & Mean & SD & Mean & SD & Mean & & SD \\
\hline Temperature $\left({ }^{\circ} \mathrm{C}\right)$ & 17.51 & \pm 1.60 & 17.35 & \pm 1.70 & 17.2 & \pm 3.47 & 19.30 & \pm & 1.93 \\
\hline Turbidity (NTU) & 16.27 & \pm 12.45 & 14.60 & \pm 9.51 & 61.67 & \pm 55.33 & 31.31 & \pm & 48.54 \\
\hline Conductivity $\left(\mu \mathrm{S} . \mathrm{cm}^{-1}\right)$ & 25.44 & \pm 4.14 & 22.89 & \pm 3.38 & 27.68 & \pm 2.54 & 28.09 & \pm 2 & 2.15 \\
\hline Dissolved Oxygen (mg. $\mathrm{I}^{-1}$ ) & 8.65 & \pm 2.49 & 10.42 & \pm 2.96 & 9.62 & \pm 4.86 & 7.49 & \pm 2 & 2.39 \\
\hline $\mathrm{pH}$ & 6.81 & \pm 0.30 & 6.41 & \pm 0.57 & 6.40 & \pm 0.80 & 6.48 & \pm & 0.57 \\
\hline Total Dissolved Solids (mg. $\mathrm{I}^{-1}$ ) & 33.78 & \pm 4.55 & 41.08 & \pm 17.86 & 33.83 & \pm 9.52 & 38.68 & \pm & 5.73 \\
\hline Total Phosphorus $\left(\mu \mathrm{g} . \mathrm{I}^{-1}\right)$ & 26.24 & \pm 25.48 & 23.36 & \pm 19.55 & 40.12 & \pm 43.76 & 29.84 & \pm & 24.63 \\
\hline $\mathrm{NO}_{3}^{-}\left(\mathrm{mg} \cdot \mathrm{I}^{-1}\right)$ & 0.02 & \pm 0.03 & 0.03 & \pm 0.03 & 0.08 & \pm 0.11 & 0.03 & \pm & 0.04 \\
\hline $\mathrm{NO}_{2}^{-}\left(\mathrm{mg} \cdot \mathrm{I}^{-1}\right)$ & 0.00 & \pm 0.00 & 0.00 & \pm 0.00 & 0.01 & \pm 0.03 & 0.00 & \pm & 0.01 \\
\hline $\mathrm{NH}_{4}^{+}\left(\mathrm{mg} . \mathrm{I}^{-1}\right)$ & 0.01 & \pm 0.04 & 0.00 & \pm 0.00 & 0.15 & \pm 0.26 & 0.01 & \pm & 0.02 \\
\hline $\mathrm{DOP}\left(\mu \mathrm{g} . \mathrm{I}^{-1}\right)$ & 57.02 & \pm 68.70 & 78.21 & \pm 82.96 & 46.04 & \pm 60.02 & 71.60 & \pm & 77.04 \\
\hline Width (m) & 3.85 & \pm 0.76 & 4.27 & \pm 1.43 & 2.32 & \pm 0.42 & 3.17 & \pm & 0.63 \\
\hline Depth (m) & 0.37 & \pm 0.15 & 0.33 & \pm 0.08 & 0.66 & \pm 0.15 & 0.78 & \pm & 0.37 \\
\hline Current speed $\left(\mathrm{m} . \mathrm{s}^{-1}\right)$ & 0.31 & \pm 0.16 & 0.32 & \pm 0.05 & 0.47 & \pm 0.09 & 0.37 & \pm & 0.10 \\
\hline Canopy Cover (\%) & 86.25 & \pm 12.75 & 81.25 & \pm 14.58 & 3.38 & \pm 5.04 & 38.50 & \pm & 20.62 \\
\hline Trunk density $\left(\mathrm{m}^{2}\right)$ & 7.98 & \pm 9.56 & 14.81 & \pm 18.75 & 2.93 & \pm 4.88 & 4.73 & \pm & 7.05 \\
\hline Riffles (\%) & 18.13 & \pm 12.23 & 38.75 & \pm 28.00 & 51.88 & \pm 35.15 & 53.75 & \pm & 34.72 \\
\hline Pools (\%) & 26.25 & \pm 18.27 & 24.38 & \pm 11.78 & 9.38 & \pm 7.29 & 1.25 & \pm & 3.54 \\
\hline Discharge $\left(\mathrm{m}^{3} \cdot \mathrm{s}^{-1}\right)$ & 1.72 & \pm 1.22 & 1.74 & \pm 0.93 & 1.58 & \pm 0.50 & 2.33 & \pm & 1.09 \\
\hline Sand (\%) & 87.50 & \pm 4.11 & 90.50 & \pm 1.77 & 91.00 & \pm 1.85 & 91.00 & \pm & 1.85 \\
\hline Clay (\%) & 8.50 & \pm 2.78 & 4.50 & \pm 0.93 & 4.50 & \pm 0.93 & 6.00 & \pm & 1.51 \\
\hline Silt (\%) & 4.00 & \pm 1.51 & 2.50 & \pm 0.93 & 2.00 & \pm 0.00 & 3.00 & \pm & 1.07 \\
\hline HQI & 148.1 & \pm 14.9 & 149.6 & \pm 21.5 & 145.0 & \pm 28.9 & 136.2 & \pm & 16.2 \\
\hline
\end{tabular}


Table 2. Loadings of the abiotic variables on the first two principal components (PC) and the proportion of variance explained by each component.

\begin{tabular}{lrr}
\hline \multicolumn{1}{c}{ Parameter } & \multicolumn{1}{c}{ PC1 } & \multicolumn{1}{c}{ PC2 } \\
\hline Eigenvalue & 6.567 & 4.222 \\
\% variance explained & 27.361 & 17.592 \\
Cumulative percentage variance & 27.361 & 44.953 \\
explained & & \\
Variables & & \\
Temperature & -0.594 & 0.447 \\
Turbidity & -0.209 & -0.522 \\
Electrical Conductivity & -0.634 & 0.094 \\
Dissolved Oxygen & 0.042 & -0.045 \\
pH & 0.683 & -0.222 \\
Total Dissolved Solids & 0.171 & -0.013 \\
NO ${ }^{-}$ & -0.871 & 0.041 \\
NO $_{2}^{-}$ & -0.558 & -0.049 \\
NH $_{4}^{+}$ & -0.608 & -0.108 \\
Dissolved Organic Phosphorus & -0.618 & 0.499 \\
Total Phosphorus & -0.736 & 0.228 \\
Width $_{\text {Depth }}$ & 0.268 & 0.709 \\
Coarse Sand $_{\text {Canopy Cover }}$ & -0.513 & -0.455 \\
Trunks $_{\text {Riffles }}$ & -0.124 & -0.304 \\
Pools $_{\text {Flow }}$ & 0.415 & 0.730 \\
\hline & 0.667 & -0.005 \\
& 0.253 & -0.504 \\
& 0.350 & 0.522 \\
& -0.257 & 0.369 \\
\hline
\end{tabular}

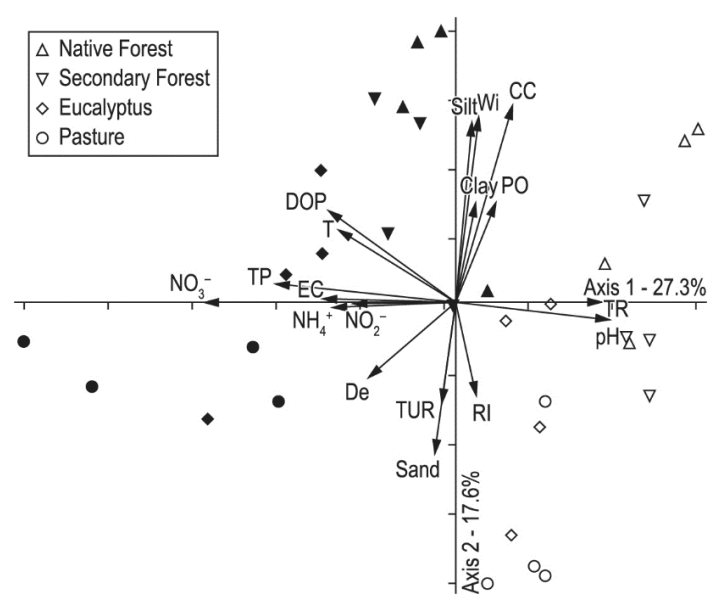

Figure 3. Principal components analysis (PCA) plot of the abiotic variables measured along the upper-middle course of the Paraitinga River, considering four different riparian conditions for the dry and rainy seasons. Environmental variables are indicated by vectors. Open symbols - dry season, full symbols - rainy season. EC - electrical conductivity; TP - total phosphorus; DOP - dissolved organic phosphorous; TDS - total dissolved solids; $\mathrm{T}$ - temperature; $\mathrm{DO}$ - dissolved oxygen, TUR - turbidity; De - depth; FL - flow; PO - pools; Wi - width; CC - canopy cover; TR - trunk and root density; $\mathrm{Ri}$ - riffles.
(T, $\mathrm{pH}$, conductivity, $\mathrm{NO}_{3}^{-}, \mathrm{NO}_{2}^{-}, \mathrm{NH}_{4}^{+}, \mathrm{DOP}$ and $\mathrm{TP}$ ) is shown in Figure 4, indicating a longitudinal gradient only for temperature and conductivity. Point specific increases were observed especially at pasture sites for the different nitrogen compounds and total phosphorus during the rainy season. DOP, $\mathrm{NO}_{3}^{-}, \mathrm{NO}_{2}^{-}$and $\mathrm{NH}_{4}^{+}$were only detected during the rainy season, and were below the detection limits of the method in the dry season, showing the highest values at the secondary forest sites.

\section{Discussion}

The Paraitinga River, together with the Jundiaí-Mirim, Biritiba and Taiaçupeba are the main tributaries of the Tietê River at its headwaters, comprising the most important sources of water supply for the metropolitan Region of São Paulo city (FUSP, 2002). Within the Upper Tietê River Basin, the sub-basin of the Tietê Cabeceiras where the Paraitinga River is located is considered the area with best water quality, in contrast to the poor water quality of surface water of the other courses (FUSP, 2002).

We demonstrated through our results that the limnological parameters of the Paraitinga River were in general within the limits established by CONAMA Resolution 357 (Class 2) of the National Commission of the Environment (Conselho Nacional do Meio Ambiente, CONAMA) (Brasil, 2005), which determines the limits for the protection of aquatic communities, supply and recreation. Exceptions were observed for turbidity and total phosphorus, which exceeded the established limits of $100 \mathrm{NTU}$ and $0.05 \mathrm{mg} . \mathrm{L}^{-1}$ respectively. Turbidity values were considered high when compared with ten other rivers in São Paulo State studied by Maier et al. (1985), who found values ranging between 9 and 33 NTU, with those rivers located over crystalline rock, such as the Paraitinga River, showing the lowest turbidity levels (1 to 2 NTU).

Total phosphorus, which is considered a measure of overall P availability (Dodds, 2003), was generally low, where the highest values were seen during the rainy season at pasture sites. Allan \& Castillo (2007) reported that large rivers of the Neotropics, with areas of extensive undisturbed forest underlain by crystalline rock, can have very low P concentrations. In undisturbed clear and blackwater tributaries of the Orinoco Basin, Venezuela, the upper range of TP has been found to be below 0.01 mg.L. ${ }^{-1}$ (Castillo et al., 2004). In the Paraitinga River, 
values above $0.05 \mathrm{mg} . \mathrm{L}^{-1}$ were found at native forest and eucalyptus sites during the rainy season, which may indicate that the forest canopy may also be a source of $\mathrm{P}$ because of leaching when rain and cloud water drip from vegetation surfaces (Allan \& Castillo, 2007).
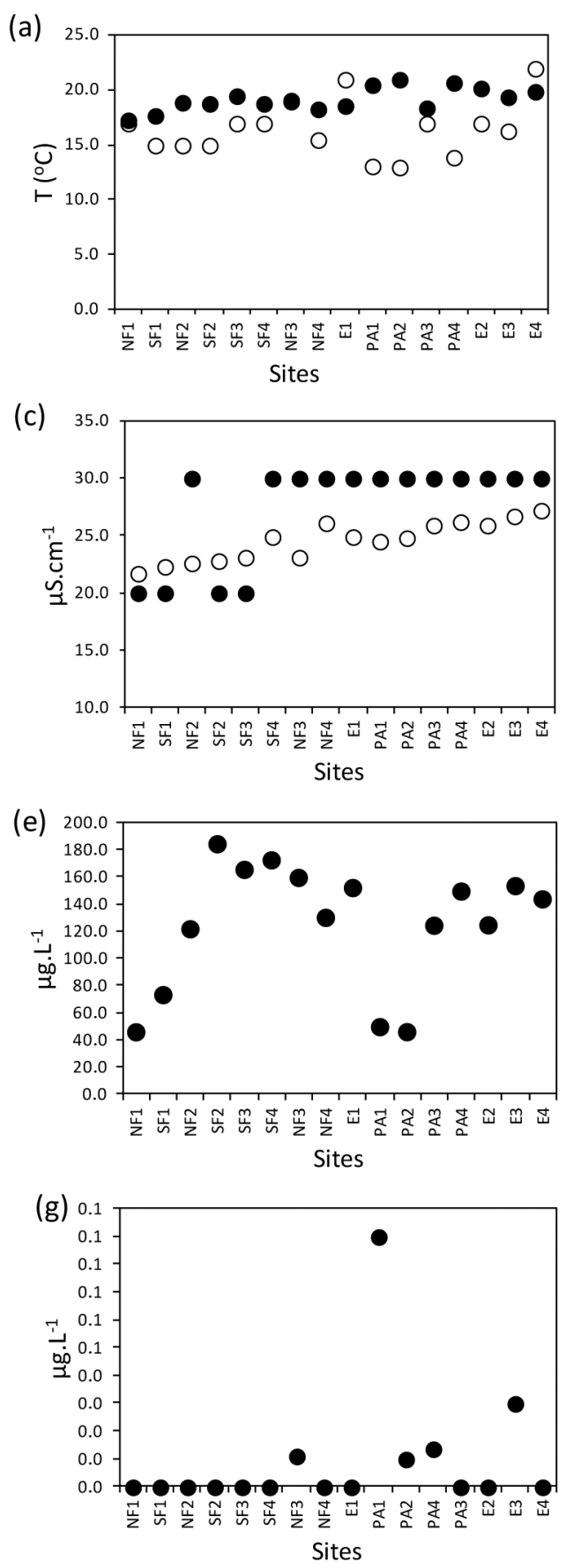

Nitrogen concentrations are strongly influenced by land use in settled areas (Allan \& Castillo, 2007), and especially by farming, which involves agricultural fertilizers, $\mathrm{N}$-fixing crops and human and animal waste (Boyer et al., 2002). Lowest values occur in areas with higher amounts of vegetation

(b)

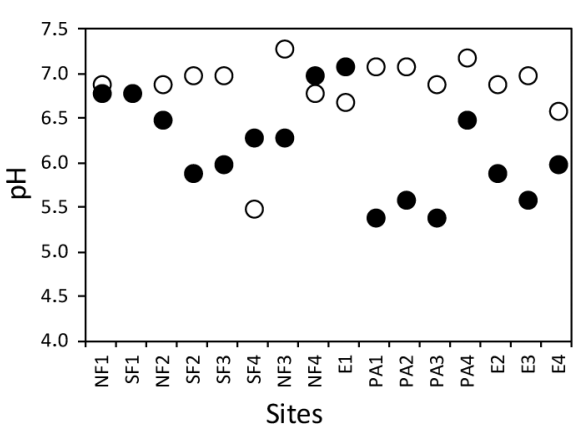

(d)
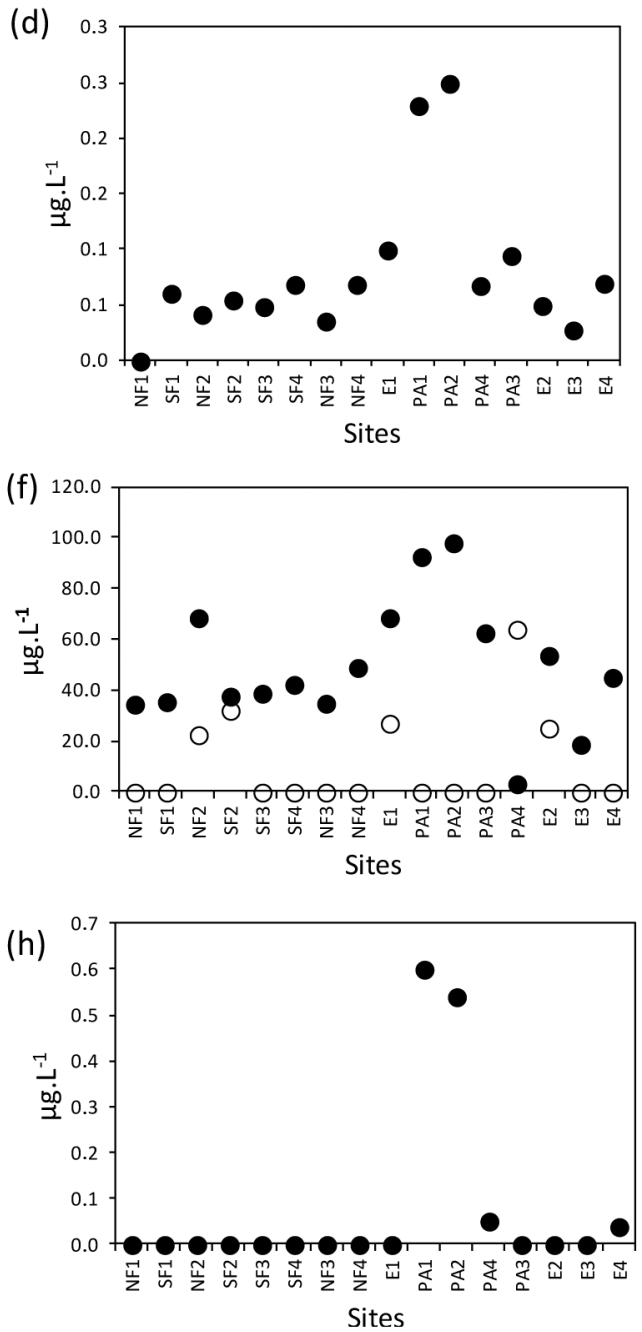

Figure 4. Longitudinal variation of the most important physicochemical parameters related to the environmental gradient along the Paraitinga River for the dry and rainy seasons. Rainy season - filled circles; dry season - open circles. (a) - Temperature; (b) $\mathrm{pH}$; (c) conductivity; (d) $\mathrm{NO}_{3}^{-}$; (e) dissolved organic phosphorus; (f) total phosphorus; (g) $\mathrm{NO}_{2} ;$; (h) $\mathrm{NH}_{4}^{+}$. NF - native forest; $\mathrm{SF}$ - secondary forest; EU - eucalyptus; PA- pasture. 
and runoff, as also observed in the Paraitinga River, where nitrate and nitrite were undetectable at most sites, except pasture areas. These results may also be related to the observations of Filoso et al. (2003), who studied land use and nitrogen export in the Piracicaba River (SP) and suggested that cultivation of pine and eucalyptus trees buffers the impact of increasing $\mathrm{N}$ inputs, because extensive cultivation of these trees have a high $\mathrm{N}$ retention capacity as they are subjected to successive biomass removal (Vitousek et al., 1997).

Considering the spatial variation of the different habitats and some limnological variables along the Paraitinga River, it must be considered that gradients of anthropogenic land use are frequently superimposed on an underlying gradient of geological material, soil type, topography, and other features of the natural terrain. Also, different environmental variables of streams can be expected to vary in their responsiveness to large versus local-scale environmental factors. Nutrients and sediments can be transported long distances and may therefore be influenced by riparian conditions along a stream's entire length, and thus, interpretation of the data must consider the influence of these different spatial scales (Allan, 2004).

In the Paraitinga River, the longitudinal influence on the different abiotic conditions as predicted by the River Continuum Concept (Vannote et al., 1980) may have been minimized because the selected stretch was limited to the upper-middle course of the river and because most sites were of the same order. Nevertheless, PCA of the habitat parameters showed that the proportion of pools and trunks and substrate composition differed between the upstream and middle portion of the river, which might have been related to both their location and point specific effects related to land use. Different riparian conditions might have contributed to the observed variations, since it has been shown that riparian forest ecosystems provide structural components, such as large woody debris (LWD), which affect stream morphology, influencing its width and depth and creating channel habitat units (pools and waterfalls) (Rosenfeld \& Huato, 2003). Pasture and eucalyptus sites were deeper and narrower, and this could have been related to the observed relation between riparian vegetation and morphological characteristics of rivers observed by several studies. Sweeney (1993) showed that the channel narrows and deepens in the grassy stretches and that the planting of trees in grassy riparian areas has the potential to cause streams to become wider and shallower as their shape adjusts to the change in bank stability (Davies-Colley, 1997)

Spatial variations in water quality were related mainly to increasing temperature and conductivity in the downstream direction. Nevertheless, point specific increases in inorganic forms of nitrogen and total phosphorus were observed during the rainy season at the pasture sites, and might have been due to the fact that in pastures and agricultural areas, erosion and runoff increase nutrient input into the streams leading to excess algal growth (Wear et al., 1998). Another potential nutrient source was the livestock present at these sites, which might have contributed with nonpoint nutrient inputs. At pasture and eucalyptus sites, turbidity was also always higher than at the native and secondary forest sites, possibly due to both land use and the sites' position along the river. Logging, especially extensive clear-cutting, increases soil loss in the basin and siltation of the streambed as shown in studies performed in Portugal by Graça et al. (2002). These authors stressed the importance of forest practices in the structure and function of stream systems, suggesting that it is necessary to keep riparian buffer strips of native vegetation to reduce the human impact on streams and rivers.

In conclusion, while few limnological parameters varied spatially along the river stretch studied, changes in some stream habitat characteristics were more pronounced. Although a direct influence on the observed variables could not be attributed solely to the riparian vegetation, this seemed to affect particular stream characteristics. Open pasture and eucalyptus sites were subjected to point specific effects that caused higher nutrient inputs, turbidity and temperature, and showed different morphological features as narrow widths and higher depth, which suggests that local land use was an important factor affecting stream conditions.

\section{Acknowledgements}

The authors thank the University of Mogi das Cruzes (UMC) and Instituto de Pesca/APTA/SAA for the infrastructure support, André Fernando de Oliveira (UMC) for limnological analysis, Marcos R. Lunardi for map making, and Jener F. Leite de Moraes (IAC) for providing soil use maps. We are also grateful to Companhia Suzano de Papel e Celulose, who provided financial support and a MSc scholarship for the second author as well as for the conditions for the field work, and to the technician Sérgio Luis da Silva (IP) for help with field work. A. Leyva helped with English editing of the manuscript. 


\section{References}

ALLAN, J.D. Landscapes and riverscapes: the influence of land use on stream ecosystems. Annual Review of Ecology Evolution and Systematics, 2004, 35(1), 257-284. http://dx.doi.org/10.1146/annurev. ecolsys.35.120202.110122.

ALLAN, J.D. and CASTILLO, M. Stream ecology: structure and function of running waters. Dordrecht: Springer, 2007, 1 p. http://dx.doi.org/10.1007/9781-4020-5583-6.

AMERICAN PUBLIC HEALTH ASSOCIATION APHA. Standard methods for the examination of water and wastewater. Washington, 1998, $1286 \mathrm{p}$.

BARBOUR, M.T., GERRITSEN, J. and SNYDER, B.D. Rapid bioassessment protocols for use in streams and wadeable rivers: periphyton, benthic macroinvertebrates and fish. Washington: U.S. Environmental Protection Agency, Office of Water, 1999. EPA/841/B-99/002.

BÄRLOCHER, F., CANHOTO, C. and GRAÇA, M.A.S. Fungal colonization of alder and eucalyptus leaves in two streams in central Portugal. Archiv für Hydrobiologie, 1995, 133, 457-470.

BOYER, E.W., GOODALE, C.L., JAWORSKI, N.A. and HOWARTH, R.W. Anthropogenic nitrogen sources and relationships to riverine nitrogen export in the northeastern USA. Biogeochemistry, 2002, 57(1), 137169. http://dx.doi.org/10.1023/A:1015709302073.

BRASIL. Resolução CONAMA n ${ }^{\circ}$ 357, de 17 de março de 2005. Diário Oficial da República Federativa do Brasil, Poder Executivo, Brasília, DF, 18 mar. 2005, Seção 1, p. 58.

CÂMARA, C.D. and LIMA, W.D.P. Corte raso de uma plantação de Eucalyptus saligna de 50 anos: impactos sobre o balanço hídrico e a qualidade da água em uma microbacia experimental. Scientia Florestalis, 1999, 56, 41-58.

CAMARGO, O.A., MONIZ, A.C., JORGE, J.A. and VALADARES, J.M.A.S. Métodos de análise química, mineralógica e física de solos do Instituto Agronômico de Campinas. Campinas: Instituto Agronômico, 2009, 77 p. Boletim Técnico do Instituto Agronômico, vol. 106

CASTILLO, M.M., ALLAN, J.D., KLING, G.W. and SINSABAUGH, R.L. Seasonal and interannual variation of bacterial production in lowland rivers of the Orinoco basin. Freshwater Biology, 2004, 49(11), 1400-1414. http://dx.doi.org/10.1111/j.13652427.2004.01277.x.

DAVIES-COLLEY, R.J. Stream channels are narrower in pasture than in forest. New Zealand Journal of Marine and Freshwater Research, 1997, 31(5), 599608. http://dx.doi.org/10.1080/00288330.1997.9 516792.

DODDS, W.K. The misuse of inorganic $\mathrm{N}$ and soluble reactive $\mathrm{P}$ to indicate nutrient status of surface waters. Journal of the North American Benthological Society, 2003, 22(2), 171-181. http://dx.doi. org/10.2307/1467990.

DOUGLAS, I. Hydrological investigations of forest disturbance and land cover impacts in South-East Asia: a review. Philosophical Transactions of the Royal Society of London, 1999, 354(1391), 1725-1738. http://dx.doi.org/10.1098/rstb.1999.0516. [Series B] PMid:11605617.

ESTEVES, K.E., LOBO, A.V.P. and FARIA, M.D.R. Trophic structure of a fish community along environmental gradients of a subtropical river (Paraitinga River, Upper Tietê River Basin, Brazil). Hydrobiologia, 2008, 598(1), 373-387. http://dx.doi. org/10.1007/s10750-007-9172-4.

FOOD AND AGRICULTURE ORGANIZATION OF THE UNITED NATIONS - FAO. Proceedings regional expert consultation on Eucalyptus [online]. FAO, 1993 vol. 1 [viewed 10 June 2014]. Available from: http://www.fao.org/docrep/005/ac777e/ ac777e00.htm\#Contents.

FILOSO, S., MARTINELLI, L.A., WILLIAMS, M.R., LARA, L.B., KRUSCHE, A., BALLESTER, M.V., VICTORIA, R. and CAMARGO, P.B. Land use and nitrogen export in the Piracicaba River basin, Southeast Brazil. Biogeochemistry, 2003, 65(3), 275294. http://dx.doi.org/10.1023/A:1026259929269.

FUNDAÇÃO DE APOIO À UNIVERSIDADE DE SÁO PAULO - FUSP. Plano da Bacia do Alto Tietê. Relatório da situação dos Recursos Hidricos: revisáo I. São Paulo: Comitê da Bacia Hidrográfica do Alto Tietê, 2000 .

FUNDAÇÃO DE APOIO À UNIVERSIDADE DE SÁO PAULO - FUSP. Plano da Bacia do Alto TietêRelatório da situação dos Recursos Hidricos - Sumário Executivo. São Paulo: Comitê da Bacia Hidrográfica do Alto Tietê, 2002.

GILLIAM, J.W., OSMOND, D.L. and EVANS, R.O. Selected agricultural best management practices to control nitrogen in the Neuse River Basin. Raleigh: North Carolina Agricultural Research Service, 1997, 58 p. Technical Bulletin, 311.

GRAÇA, M.A.S., POZO, J., CANHOTO, C. and ELOSEGI, A. Effects of Eucalyptus plantations on detritus, decomposers, and detritivores in streams. The Scientific World Journal, 2002, 2, 11731185. http://dx.doi.org/10.1100/tsw.2002.193. PMid:12805976.

GREIG-SMITH, P. Quantitative plant ecology. Oxford: Blackwell Scientific Publications, 1983, 354 p.

INSTITUTO AGRONÔMICO DE CAMPINAS - IAC. Projeto Negowat [online] Campinas, 2006 [viewed 12 June 2008]. Available from: http://www. iac.sp.gov.br/indmirim/negowat/tabelas/areas.xls

KLAPPROTH, J.C. and JOHNSON, J.E. Understanding the science behind riparian forest buffers: effects on water 
quality. Virgínia: Virginia Cooperative Extension, 2000, pp. 420-451. Publication Virginia Polytechnic Institute and State University.

LOWRANCE, R., TODD, J., FAIL JUNIOR, J.R., HENDRICKSON JUNIOR, O., LEONARD, R. and ASMUSSEN, L. Riparian forests as nutrient filters in agricultural watersheds. Bioscience, 1984, 34(6), 374-377. http://dx.doi.org/10.2307/1309729.

MAIER, M.H., TAKINO, M., BASILE-MARTINS, M.A. and CIPÓLLI, M.N. River tipology of São Paulo State, Brazil. Verhandlungen des Internationalen Verein Limnologie, 1985, 22, 2161-2166.

MAITLAND, P.S., NEWSON, M.D. and BEST, G.A. The impacts of afforestation and forestry practice on freshwater habitats. UK: Nature Conservancy Council, 1990. Focus on Nature Conservation, no. 23.

MANNA DE DEUS, J.R., NICOLAU, S.A., FRIZZERBORGES, M.R., CORTEZ, L., IARTELLI, L. and SILVA, F.S.D. Biodiversidade do Alto Curso do Rio Tietê. Mogi das Cruzes: Cemasi, Universidade Braz Cubas, Universidade de Mogi das Cruzes, 2001. Relatório geral.

MCCUNE, B. and MEFFORD, M.J. 2011. PCORD. Multivariate Analysis of Ecological Data. Version 6.0. Gleneden Beach: MjM Software.

MEYER, J.L., MCDOWELL, W.H., BOTT, T.L., ELWOOD, J.W., ISHIZAKI, C., MELACK, J.M., PECKARSKY, B.L., PETERSON, B.J. and RUBLEE, P.A. Elemental dynamics in streams. Journal of the North American Benthological Society, 1988, 7(4), 410-432. http://dx.doi.org/10.2307/1467299.

MORAES, J., CARVALHO, J.P. and CARLSTROM FILHO, A.A. Caracterização e evolução do uso das terras na Sub-bacia Tietê-Cabeceiras [online]. Negowat, 2005 [viewed 3 Jan 2014]. Negowat Workpackage 3 Report. Available from: http://negowat.cirad.fr/Docs $4 \mathrm{Web} /$ Brazil_pdf/10_\%20Brazil.pdf

MULHOLLAND, P.J. Regulation of nutrient concentrations in a temperate forest stream: roles of upland, riparian and instream processes. Limnology and Oceanography, 1992, 37(7), 1512-1526. http:// dx.doi.org/10.4319/lo.1992.37.7.1512.

NEWBOLD, J.D., O’NEILL, R.V., ELWOOD, J.W. and VAN WINKLE, W. Nutrient spiralling in streams: implications for nutrient limitation and invertebrate activity. The American Naturalist, 1982, 120(5), 628-652.
PECK J.E. Multivariate Analysis for community ecologists: step-by-step using PC-ORD. Oregon: MjM Software Design, 2010, $162 \mathrm{p}$.

ROSENFELD, J.S. and HUATO, L. Relationship between large woody debris characteristics and pool formation in small coastal British Columbia streams. North American Journal of Fisheries Management, 2003, 23(3), 928-938. http://dx.doi.org/10.1577/ M02-110.

SIMÔES, L.B. A importância das matas ripárias para controle da poluiçấo difusa. In R. HENRY, eds. Ecótonos nas interfaces dos ecossistemas aquáticos. São Carlos: RIMA, 2003, 349 p.

SWEENEY, B.W. Effects of streamside vegetation on macroinvertebrate communities of White Clay Creek in eastern North America. Proceedings of the Academy of Natural Sciences of Philadelphia, 1993, 144, 291-340.

TABACCHI, E., CORRELL, D.L., HAUER, R., PINAY, G., PLANTY-TABACCHI, A.-M. and WISSMAR, R.C. Development, maintenance and role of riparian vegetation in the river landscape. Freshwater Biology, 1998, 40(3), 497-516. http:// dx.doi.org/10.1046/j.1365-2427.1998.00381.x.

VANNOTE, R.L., MINSHALL, G.W., CUMMINS, K.W., SEDELL, J.R. and CUSHING, C.E. The river continuum concept. Canadian Journal of Fisheries and Aquatic Sciences, 1980, 37(1), 130-137. http:// dx.doi.org/10.1139/f80-017.

VITOUSEK P.M., ABER J.D., HOWARTH R.W., LIKENS G.E., MATSON P.A., SCHINDLER, D.W., SCHLESINGER, W.H. and TILMAN, D.G. Human alteration of the global nitrogen cycle: sources and consequences. Ecological Applications, 1997, 7, 737-750.

WARD, J.V. Riverine landscapes: biodiversity patterns, disturbance regimes, and aquatic conservation. Biological Conservation, 1998, 83(3), 269-278. http:// dx.doi.org/10.1016/S0006-3207(97)00083-9.

WEAR, D.N., TURNER, M.G. and NAIMAN, R.J. Land cover along an urban-rural gradient: implications for water quality. Ecological Applications, 1998, 8, 619-630.

Received: 12 November 2014 Accepted: 24 April 2015 